This is an electronic reprint of the original article. This reprint may differ from the original in pagination and typographic detail.

Author(s): Ojala, Jari; Luoma-aho, Vilma

Title: Stakeholder relations as social capital in early modern international trade

Year: $\quad 2008$

Version:

Please cite the original version:

Ojala, J. \& Luoma-aho, V. (2008). Stakeholder Relations as Social Capital in Early Modern International Trade. Business History, 50 (6), 749-764.

DOI:10.1080/00076790802420310

All material supplied via JYX is protected by copyright and other intellectual property rights, and duplication or sale of all or part of any of the repository collections is not permitted, except that material may be duplicated by you for your research use or educational purposes in electronic or print form. You must obtain permission for any other use. Electronic or print copies may not be offered, whether for sale or otherwise to anyone who is not an authorised user. 


\section{Stakeholder Relations as Social Capital in Early Modern International Trade}

(AUGUST 1, 2008)

Ojala, J. \& Luoma-aho, V. (2008) 'Stakeholder relations as Social Capital in Early Modern International Trade', Business History, 50(6), pp. 749 - 764. (REF)

\section{ABSTRACT}

Stakeholder relations that are available through networks of various sorts are one benefit from social capital. According to the stakeholder approach to organizations, those relationships that contain most of the important attributes - such as power, legitimacy, frequency of contact, and urgency-hypothetically dominate the business environment. This has caused modern corporations to view chiefly the dominant stakeholders as important. This study tests the importance of these attributes in early modern international trade; in other words, which attributes played a major role in the relations between Finnish tradesmen and their foreign contacts? The archives of two major Finnish trading houses from 1781-1852 provide sources to study these stakeholder relations. The results of the study seem to confirm the importance of legitimacy and power in stakeholder relations, but they particularly emphasize the significance of frequency and urgency. Furthermore, dealings repeated over time between the parties created a resource dependency, and, thus, further underlining frequency and power as important stakeholder attributes.

Keywords: Social Capital; Stakeholder relations; Early Modern Business 


\section{Introduction}

The stakeholder approach to organizations hypothesizes that those relationships that maximize certain important attributes - power, legitimacy, frequency of contact, and urgency - dominate the business environment. ${ }^{1}$ Modern corporations, according to this approach, tend to emphasize the importance of dominant stakeholders. It is unclear, however, whether these four attributes were significant and what their importance was in different periods of time - such as the early modern era, addressed in this paper. If social capital is understood as resources embedded in social networks, ${ }^{2}$ then positive stakeholder relations are highly beneficial for business: they offer reputational benefits, build trust, lower transaction costs and smooth collaboration. ${ }^{3}$

This study analyzes the social capital embedded in stakeholder relations through the relational attributes of power, legitimacy, frequency, and urgency. We ask which of these attributes contributed most to creating social capital in early modern international trade in general, and we specifically test which of them played the strongest role in the relations between Finnish tradesmen and their foreign contacts. The aim of the article is bi-directional. First, we aim to understand early modern international trade better by looking at the era through the concepts of social capital and stakeholder attributes. These concepts thus help us to create history, to build an historical narrative. At the same time, our objective is also to exploit history, that is, to develop these concepts further with the evidence from our empirical work. Unlike the emphasis of social capital theorists who analyze later times on the contents of relationships and trust, our study of the early modern era highlights the importance of frequency and repetition as among the primary factors in building such relationships and trust. ${ }^{4}$ The importance of frequency could also contribute to theorizing about social capital dynamics today.

In early modern international trade, social relations formed the basis of almost every business transaction. Exchanges generally took place between relative equals, which emphasised the important role of trust, reputation, and expectations of reciprocity. Even in international trade, where the transacting parties did not necessarily know each other personally, trust developed through repeated dealings, long-term business partnerships and the use of intermediaries. Authors like Greif (1989) and North (1981, 1990), have emphasised the personal nature and socially embedded reciprocity of the pre-industrial economy, in contrast to the relative impersonality and market-driven exchange that emerged in the early nineteenth century. ${ }^{5}$ However, there were some 
features of impersonality even in eighteenth-century transactions, and, of course, characteristics of non-market exchange still remain in our contemporary economy. ${ }^{6}$

As international trade expanded during the period from the mid-eighteenth to the mid-nineteenth century, the expansion of the number of business contacts increased impersonality in trade, as economies of specialisation gave birth to new groups of intermediaries such as trade brokers, shipping agencies and bankers, many of them operating at a distance from each other. In particular, the Finnish export trade, and concomitantly the shipping business, emerged in the eighteenth century with tar and timber as the main export items. In 1870 Finnish export commodities required around one hundred times more transport capacity than in 1760, with [move superscript to end of sentence, please] British, German, Dutch, and Swedish businessmen the most important trading contacts. ${ }^{7}$

The concept of social capital offers a useful tool even when applied retrospectively for the analysis of early modern trade practices. ${ }^{8}$ As Jon Stobart (2005) and many other scholars of past and present business practices have stressed, reputation and regard - key elements of social capital - can develop through business networks. ${ }^{9}$ Together with honour and reputation, these entrepreneurial networks, reinforced by kinship, cannot be underestimated in analysing early modern trade. ${ }^{10}$ Early modern business correspondence offers a good case to study the importance of social capital. Unlike more contemporary business practises, this correspondence records all communication between the business contacts in international trade, as no oral communication was possible over large distances. ${ }^{11}$ Furthermore, this correspondence is quite well preserved in the cases we study in this article, covering the years from the 1780 s up to the 1850 s.

In the following, we will first clarify our use of the concepts "social capital" and "stakeholder" then describe our sources and cases. In the analytical section, we will first conduct a quantitative analysis in order to reveal the importance of different stakeholder attributes, and thereafter analyse the different attributes by means of some illustrative examples. The concluding remarks and discussion will emphasise two questions. First, has this study broadened our understanding of early modern business practises? And, second, is there anything conceptually novel to be found in our inquiry? 


\section{Stakeholder relations as social capital}

Social capital is not like human capital, which resides in individuals; rather it is an asset that abides in their social relations. Social capital is one of the benefits available through social networks as it enables and rewards people who collaborate while they work to build trust, maintain norms and encourage reciprocity. Our thinking is closely related to Bourdieu's (1997) conception of social capital as "the actual or potential resources which are linked to possession of a durable network of $[\ldots]$ relationships of mutual acquaintance and recognition $[\ldots]$ which provides each of its members with the backing of the collectively-owned capital, a "credential" which entitles them to credit, in the various senses of the word". ${ }^{12}$ To function, social capital requires a social structure, such as a group joined together by a common interest. ${ }^{13}$ Social capital facilitates cooperation, and it becomes productive through communication. Social capital can flourish with ongoing interaction, in Bourdieu's words, "a continuous series of exchanges in which recognition is endlessly affirmed and reaffirmed". ${ }^{14}$ In fact, should communication fail or end, social capital erodes. ${ }^{15}$

The idea of stakeholder relations as a form of social capital springs from realizing the importance of access to information and cooperation that stakeholders possess. These relations can lower the costs of information and assistance, thereby contributing to a decrease in transaction costs. Stakeholders who are willing to collaborate vastly increase their collective chances of success. The concept of stakeholder has emerged in economics and the social sciences during the last few decades, originally born as a counterpart to the classical economic notions of shareholder value and profit maximization. It recognizes those groups whose value is not measured through profits, but who variously affect or are affected by the organization. ${ }^{16}$ Stakeholders include not only shareholders but also employees, customers, suppliers, lenders and often even society at large. ${ }^{17}$ They provide inputs or resources for a business, and they expect something in return, at least a partial satisfaction of their own needs. They hold the power both to harm and to benefit the business. ${ }^{18}$

There are different ways of categorizing stakeholders. ${ }^{19}$ Mitchell, Agle and Wood (1997) distinguish three attributes according to which stakeholders can be classified from the point of view of a business: power, legitimacy and urgency. ${ }^{20}$ The existence or lack of these attributes and their combinations, they claim, shape the importance and role of each stakeholder in relation to the business. Luoma-aho (2005) has argued for an additional attribute: frequency of contact. ${ }^{21}$ Together these four attributes form the theoretical skeleton for this study, against which we investigate the 
stakeholder relations apparent in early modern international trade. Figure 1 illustrates these four attributes.

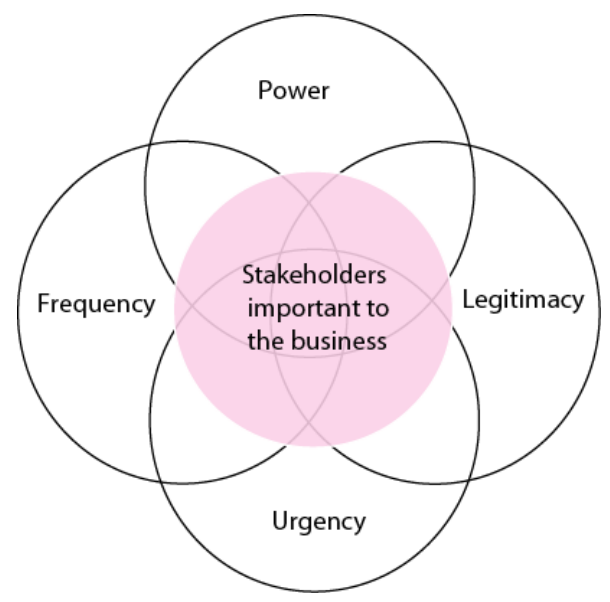

Figure 1. Stakeholder attributes

For Mitchell, Agle \& Wood (1997), power is the ability to bring about desired outcomes, to force others to behave as one wishes, whereas legitimacy refers to the degree to which the actions of an entity are generalized as desirable, proper, or appropriate. Urgency is simply the degree to which stakeholder demands require instant action from the business. Frequency refers to the continuity of the relationship and describes the number of contacts within an interval of time between the business and its stakeholders. Frequency is related to stakeholder loyalty and involvement, as only through repeated interactions is it possible to build trust and expectations, and create a lasting reputation. ${ }^{22}$ We analyze stakeholders in terms of these four attributes and their degree of presence. As an example, legitimacy and power together create authority. Stakeholders characterized by all four attributes we call definitive stakeholders, whom firms regard as holding more importance than those groups possessing only one or two of the attributes. Traditionally businesses have especially [?] focused on those stakeholders who possess power, as do stockholders and creditors, for their role and input for the business have been obvious.

\section{Sources and cases}

How can the role played by social capital in early modern business be studied? Business archives can offer empirical evidence for stakeholder relations in international trade and shipping, as basically all related communication was handled through letters. Therefore, in this study, we have analysed extant early modern trading house correspondence and ledgers. In fact, our sources 
manifest social capital, for the correspondence itself reveals "social networks of high trust", ${ }^{23}$ and the contents of the letters demonstrate the importance of that trust.

Table 1. Letters analysed in this study

\begin{tabular}{lccc}
\hline Years & Falander 1781-1812 & Franzén 1823-1852 & Together \\
\hline Number of all letters sent & 5,250 & 5,422 & 10,672 \\
Number of individual contacts in letters & 854 & 719 & 1,573 \\
Letters sent per contact & 6.1 & 7.5 & 6.8 \\
Cross-cut sample years & $1781,1795,1805,1810$ & $1825,1835,1845,1852$ &.. \\
Number of letters (sent sample years) & 647 & 878 & 1,525 \\
Number of letters received (sample years) & 400 & 638 & 1,038 \\
Number of contacts (sample years) & 222 & 287 & 509 \\
Av. Number of sent letters/contact (sample) & 2.9 & 3.0 & 3.0 \\
Av. Number of letters received /contact (sample) & 1.8 & 2.2 & 2.0 \\
Percentage of all letters sent in sample years & 12.3 & 16.2 & 14.3 \\
Percentage of all contacts in sample years & 26.0 & 39.9 & 32.4 \\
\hline
\end{tabular}

Sources: OPAS and VPAF, Correspondence.

As sources we utilise the archives of two major Finnish trading houses (Falander and Franzén) from 1781 to 1852 , which altogether hold copies of over 10,000 letters sent to about 1600 different business contacts (Table 1). In addition to this correspondence, we use the account books of these trading houses to assess the importance of the contacts in terms of the value of trade. Some other trading house archives provide a comparative perspective.

There are, however, limitations to using the business letters as sources. First of all, only the copies of sent letters have been preserved perfectly, not those received. However, in these sent letters there are usually careful references to the letters the tradesmen have received from some but not all of their business contacts. Second, as the number of letters is large, the detailed analysis of all of them is practically impossible. Therefore, we have selected four cross-cut sample years, containing altogether 1,525 sent letters and 509 individual contacts from both sources for a deeper analysis. That amounts to 14.3 per cent of all letters and almost one third of the contacts, which in turn is evidence of the concentration of business contacts (see Table 1 for details).

The businesses of Abraham Falander (1746-1815, later ennobled and granted the name Wasastjerna) and Zacharias Franzén (1787-1852, owner of the J. Lang \& Co. trading house) serve as our primary cases. At the time, they both were among the most important merchants in Finland in terms of the value of their businesses, concentrating on retail and wholesale trade, exports and imports and on shipping. ${ }^{24}$ Thus both Franzén and Falander were engaged in international business, 
where trade depended on long-distance contacts, and trust between stakeholders was especially important.

\section{Identifying stakeholder attributes}

We use frequency to assess the number of letters sent. In each cross-cut sample year, the annual average number of letters sent to all business contacts, including customers, agents and bankers, constitutes a basis for comparison. Each contact can possess several stakeholder attributes - even all of them - or none. There could be, of course, several ways of determining each stakeholder attribute. Due to the nature of the sources, we have created some rather rough estimates to make these judgements. Namely, if the number of sent letters to contacts is over the average, then we regard frequency as one of a contact's stakeholder attribute. Power, in turn, we calculate in terms of the value of trade, which we glean from the ledgers. We then compare the total value of business of each contact with the average value of business with all contacts for each year; if this value of named contact is above the average, then we judge that power is an important attribute for the stakeholder. ${ }^{25}$ The dates of the letters indicate urgency. The sent letters practically always stated which letters (if any) the Finnish merchant had received from his business contact, and also the dates of these letters. By comparing the days between the foreign business contact's date and the date when letter was sent from Finland, we can calculate the "urgency" of the business contact, namely, how urgently businessmen sought to answer these letters. This time lag we then compare to the average difference between these dates in each particular town. If the response was quicker than the average, then we can conclude that urgency was an important stakeholder attribute of that contact. Lastly, legitimacy was an attribute that some third party conferred. We identify relevant third parties here either as the state, which could be involved, for example by nominating a local tradesman as honorary consul ${ }^{26}$, or other Finnish businessmen who might legitimise the stakeholder through their familiarity with him/them. A lack of other traders' correspondence makes legitimacy a somewhat vague attribute, and therefore, the research results on this dimension should be considered as tentative.

Table 2. Percentage of different stakeholder attributes in Falander's and Franzen's contacts (sample years, $N=509$ contacts)

\begin{tabular}{lccc}
\hline & Falander & Franzén & Together \\
\hline Frequency & 31.1 & 23.7 & 26.9
\end{tabular}




\begin{tabular}{lccc} 
Power & 14.9 & 14.3 & 14.5 \\
Urgency & 30.6 & 37.3 & 34.4 \\
Legitimacy & 9.9 & 17.4 & 14.4 \\
\hline All 4 attributes & 3.2 & 3.8 & 3.5 \\
3 attributes & 6.8 & 8.7 & 7.9 \\
2 attributes & 12.2 & 7.3 & 9.4 \\
1 attribute & 29.3 & 36.6 & 33.4 \\
No attributes & 48.6 & 43.6 & 45.8 \\
\hline
\end{tabular}

Note: frequency = number of letters sent to the contact is above the average; power $=$ the value of trade with the contact is above the average; urgency = time in days between the date of the received letter to the date of the sent letter is below average in comparison to other letters sent to the same place; legitimacy = the contact is mentioned in other traders' correspondence and/or the contact is a local consul.

Sources: OPAS and VPAF, Correspondence and ledgers.

There are not many definitive stakeholders, i.e. those possessing all four stakeholder attributes (Table 2): altogether 18 stakeholders (3.5\% of 509) can be regarded as definitive. Those contacts with most of the stakeholder attributes were specialised trade brokers and bankers who had the most frequent contacts with Finnish businessmen, and the value of their business was obviously high as most of the transactions were handled through them.

The importance of brokers and bankers is no surprise; Falander sent around half of the letters to them. Only seldom were there direct communications with "ultimate" customers, for example, letters to persons who bought export cargoes carried on Finnish ships. Instead trade brokers handled most of the transactions in international trade as middlemen between the ultimate producer and the customer. These middlemen handled information within the networks of international trade. They usually did not handle the products physically but gave advice on where they should be delivered. ${ }^{27}$ In most cases, Finnish tradesmen never met these vital contacts in person. Thus, according to the thinking of Granovetter (1973), they were close to what has been described as "weak ties"; not strong, but essential for business. ${ }^{28}$

In the case of Falander, there were only seven contacts out of 222 during the sample years that possessed all of the stakeholder attributes. These definitive stakeholders included his most important business contacts in Sweden, Denmark, the Netherlands, and in Spain. Of these, only two contacts possessed all four attributes in two of the sample years, the Hasselgren trading house in Amsterdam and the business of Anders Rosendahl in Stockholm. Both of these contacts were trading houses that specialised in ship-broking and banking, and most of Falander's bills of exchange were handled through them. The owner of the Hasselgren trading house, Conrad Hasselgren, was also the local Swedish honorary consul in Amsterdam. In 1785, for example, the Hasselgren firm handled over fifty-five per cent of the value of Falander's foreign trade. ${ }^{29}$ 
In the case of Franzén, eleven contacts out of 287 possessed all four stakeholder attributes during all the four sample years, including his important business contacts in Finland, Sweden, Russia, Denmark, and Britain. Of these, four possessed all attributes in two sample years. These four most important contacts were the Sterky trading house in St. Petersburg (four attributes in 1845 and 1852), the Holm shipping agency in Elsinore, Denmark (1835 and 1852), the Coninck trading house in Copenhagen (1835 and 1852) and the Sutthoff trading house in Stockholm (1825 and 1835).

As can be seen from Table 2, frequency and urgency were the most common stakeholder attributes, as in both cases roughly one third of the contacts possessed urgency and one fourth frequency. One out of seven contacts had power or legitimacy as a stakeholder attribute. An interesting finding in Table 2 is the fact that almost half of the contacts did not possess any of the stakeholder attributes. These were occasional contacts to whom letters were sent only once or twice. The business carried out with them was also insignificant in terms of value. Most often these were domestic contacts, but there were also occasional foreign businessmen to whom letters were sent in order to open business relations - unsuccessfully. Clearly, both Falander and Franzén put a lot of effort and energy into these occasional contacts, though most of the business was handled through a fairly limited number of actors with several stakeholder attributes.

In the following, some illustrative examples offer a more detailed analysis of the different stakeholder attributes. We will also define these attributes further in order to analyse some of their characteristics that did not show up in the quantitative analysis above. Based on our experience, we believe that our cases and, thus, also the ways these attributes show up were rather typical at the time.

\section{Frequency}

Frequency refers to the continuity of a relationship and refers to the amount and reoccurrence of exchanges or contacts with the stakeholders. ${ }^{30}$ Frequency can refer to the number of personal meetings, as well as to the number of times the contact comes up on other occasions and in social networks. Frequency can be a product of both personal and mediated contact and interaction. In Table 2, altogether 133 contacts were considered as "frequency-enforced", that is around one quarter of all the contacts. These most frequent contacts were usually also the ones whose trade held 
the most value. This is no surprise: it is natural that letters were sent to those who were also important in terms of the value of business.

Besides the number of contacts, frequency as a stakeholder attribute also implies long-term involvement with historical trajectories in which trust develops from reputational experiences. ${ }^{31}$ This can be seen in the longevity of key business contacts; certain agencies abroad served Finnish trading houses for decades. ${ }^{32}$ All transacting parties bring their own histories and experiences into the stakeholder networks, and hence these networks became more than the mere sum of their participants. Though these parties did not necessarily know each other personally, they learned more about each other in time through repeated dealings, and thus transactions gained more personal characteristics. This kind of personalised trade lowered the uncertainties and costs of transaction.

An example of a long-term business contact in Finnish foreign trade and shipping of this era was the Sterky trading house in St. Petersburg. Sterky was among the definitive stakeholders in Franzén's business, as in two sample years (1845 and 1852) it evinced all four stakeholder attributes, and in 1835 two attributes (power and legitimacy). Franzén had his first contacts with Sterky in 1827 , when this Russian trading house handled some money transfers for him. ${ }^{33}$ In each of the following couple of years, Franzén sent only one letter to Sterky, whereas in 1830 he sent altogether 13 letters there. In the period from 1827 to 1852, Franzén sent 208 letters to the Sterky trading house, constituting four per cent of all letters he sent during the whole period analysed $(1823-1852) .^{34}$

In this analysis, frequency is a product of the number of annual contacts, together with the longevity of the contacts. The early modern businessmen studied here clearly preferred longevity and concentration in business contacts with certain trading houses abroad; that is, frequency was clearly among the most important stakeholder attributes in trade at the time. Frequent contacts, then as now, went a long way toward advancing social capital and its benefits.

Power

Power as a stakeholder attribute refers to the stakeholders' ability to influence the business; it is a matter of control and dependence. ${ }^{35}$ Power is the ability to bring about desired outcomes. Thus the attribute of stakeholders' power can be also viewed from the resource dependency perspective. ${ }^{36} \mathrm{We}$ 
calculated power as a stakeholder attribute in Table 2 by assessing the value of businesses with different stakeholders. The value of business, however, does not necessarily reveal the whole importance of the stakeholder, as some stakeholders also possessed an important intangible asset in trade, namely, information. Thus, power as a stakeholder attribute relates not only to the value of business but also to the place of the stakeholder in an information-sharing network.

The Finnish principals depended on the information and other services provided by their foreign agencies. At the same time, however, the specialised agencies also depended on their principals because their whole business activity was based on the commissions from the transactions provided by the principals. The possibility for the agent to monitor and check up on his principal—or vice versa-depended on power. According to theories of social exchange, the inter-organizational power of an actor depends on his ability and opportunities to control vital resources. ${ }^{37}$

In Table 2, altogether 74 out of 509 contacts possessed measurable power as a stakeholder attribute; that is, the value of trade with these contacts exceeded the average in each cross cutting sample year. The share of "power-enforced" stakeholders was roughly the same in both cases, around 14 to 15 per cent. These were the actors in international trade that also transferred information in the form of bills of exchange as trading houses involved in brokerage and banking activities.

Power as a stakeholder attribute through resource dependence can be clearly seen when foreign business associates were in financial difficulties; such crises also sometimes harmed the business of Finnish trading houses. An illustration of destroyed trust is the bankruptcy of Daniel Sutthoff \& Co. in December 1842. The Sutthoff trading house in Stockholm was one of the definitive stakeholders in Zacharias Franzén's trade; the number of letters he sent to Sutthoff's house was the largest in the period 1821-1852, totalling 395 letters (7.3 per cent of all letters sent). The Sutthoff crash came as a surprise to Franzén. In a letter after the bankruptcy to a contact of the Sutthoff trading house, Anders Wener, Franzén clearly gave vent to his outrage at the business failure. He elaborated on how he had deeply trusted in their "truthfulness and solidity" for over twenty years. The account books reveal, though, that Franzén was already suspicious of Sutthoff's viability before the bankruptcy: the value of trade through Sutthoff had declined already since 1841. Furthermore, up until the crash, no more bills of exchange from abroad were transferred through Suthoff. ${ }^{38}$

There are also examples where foreign agents secured the interests of their Finnish principals in times of crises, demonstrating the power of stakeholders. This occurred, for example, in the case of 
Rew, Prescott \& Co in London after the death of one of the contacts of the company, H. J. Prescott, in 1856. The most notable Finnish ship- owner at the time, Peter Malm Jr had invested capital significantly through this London house. Therefore, Peter Malm sent his son Otto August Malm to London to attend to his interests. However, Rew, Prescott \& Co. had already secured the interests of its important principal in Finland by transferring Malm's investments to another, more solid London-based firm. After Rew's company survived its crisis, Malm felt even greater confidence in his old business associate. Therefore, it is no wonder that Rew's company remained one of the most important contacts in Malm's trading house up to the $1890 \mathrm{~s}^{39}$

Both of these cases were rather typical at the time, showing how difficult it was for a principal to monitor his overseas agents. They also show how trustfulness was sometimes achieved and sometimes lost through repeated dealings.

\section{Legitimacy}

Legitimacy refers to general acceptance and good standing. ${ }^{40}$ It is related to legal and approved matters or relations to rights and titles, often established through contracts, exchanges or agreements. ${ }^{41}$ The importance of legitimacy often becomes apparent only upon a threat of losing it. Legitimacy is also related to responsibilities, whether moral or legal, toward others in society. Thus legitimacy is something that is especially close to the most common definition of "social capital," confering "generalised trust", enforced by society as a whole or by third parties. In this study, third parties included other Finnish businessmen, personal intermediaries, and the state. In Table 2 the number of these "legitimacy-enforced" contacts was 72, that is around 14 per cent of all cases. Legitimacy and power together create the authority of the stakeholder. Altogether only around eight per cent of all contacts possessed authority in this sense.

The business society at large could act as a third party to judge the legitimacy of stakeholders and thereby help to enforce the credibility of their interactions. ${ }^{42}$ This can be seen in the way foreign agencies recommended each other and from the fact that Finnish businessmen tended to use the same agencies abroad. Foreign agencies frequently listed their world-wide networks of contacts or their "friends" in their correspondence, demonstrating their own and their associates' legitimacy to their Finnish principals. This can be detected in the circular letters overseas agencies sent to Finnish trading houses to promote their trade. For example, Fredholm \& Ekström from Marseilles declared in an 1856 circular that twenty out of fifty Nordic ships that put into Marseilles used their services. 
Moller \& Co. boasted that they had cleared nineteen out of 34 Finnish ships that had docked in the port of Lisbon in $1840 .{ }^{43}$ Finnish tradesmen also recommended their agencies to each other. Abraham Falander, for example, recommended the Lautier trading house and its agent Gladberg to other Finnish businessmen in neighbouring towns. ${ }^{44}$

Personal intermediaries also served as third parties to ensure the legitimacy of the overseas agencies. Shipmasters played an especially important role in evaluating the reliability of overseas contacts and in concluding agreements with them. Foreign agencies also considered shipmasters to be the "first-grade agents" of the Finnish trading houses. For example, in the late 1820s Peter Malm Jr fumed when he noted that the shipmaster R. W. Backman had, against his directions, taken out insurance for his ship "The Enterprise" with the Clay trading house in Hull, England. Malm blamed Clay's house for this error because he did not want to have the ship insured. In his response, Clay referred to the important role played by the shipmaster: "... it may be that Backman has no authority from you to take out insurance - but just take a look at our position and then say if we had any authority to refuse to take such orders as we received from him, the captain being always considered the authoritative agent and representative of the owner... ". ${ }^{45}$ Usually, however, it was the task of the shipmaster to evaluate the legitimacy of the agencies rather than vice versa, as the shipmasters were the ones to make many decisions in practice as they had no possibility orders immediately from their principals due to the slow speed of information.

The state, too, could act as a third party to enforce the legitimacy of the overseas agencies. The commercial services provided by the Nordic states during the seventeenth and the eighteenth centuries were especially important for mercantile activities. The establishment of honorary consular services represented the state's attempt to externalise the transaction costs of its own nation's merchants. These honorary consuls were in most cases local businessmen who did not get any fixed salary from the states they represented. However, they could use their consular assignment as a competitive advantage in their business relations. The consular service on the one hand helped ships in foreign ports, and on the other hand also provided a tool for information gathering. ${ }^{46}$

Consular services were particularly important in distant areas where businessmen had not yet acquired any business contacts. During the years under Swedish rule (up to 1809), Swedish consulate networks, especially in the Mediterranean area, were important to Finnish export businesses. The important role played by the consuls in business is clearly apparent in Falander's 
trade. Between 1785 and 1815, about one-third of Falander's transactions, representing more than a quarter of the value of his foreign trade, was carried out through consuls, who accounted for twentyseven per cent of all foreigners with whom Falander had trading relationships at the beginning of the nineteenth century. Even in 1815, after Finland was annexed to Russia, seventeen per cent of Falander's transactions, amounting to almost one-third of the value of his trade, went through agents that were at the same time Swedish honorary consuls. ${ }^{47}$

Legitimacy as a stakeholder attribute is, therefore, here understood as something gained through third-party engagement. In the early modern context, these third parties comprised the business society as a whole, personal intermediaries in trade and the state as a provider of consular and other services.

Urgency

Urgency relates to the emphasis and force placed on the stakeholders' claims. It is manifest when stakeholders require immediate attention or other issues are time-sensitive. It refers to the ability to obtain and hold attention. ${ }^{48}$ We identify urgency by the pace or haste of taking action. Although we ascribe urgency to different actions that may not involve similar periods of time, we always identify it according to those issues on which our subjects placed the utmost importance. In Table 2, we identified altogether 175 contacts during the sample years as "urgency-enforced". Our analysis shows that Finnish principals tried to answer to the letters they received as soon as possible. Urgency was, however, a somewhat relative concept in early modern trade as business was dependent on rather slow information flows through the postal services. Though the speed of information did accelerate, the communication in international business was anything but fast. ${ }^{49}$ Even so, our analysis suggests that our subjects regarded urgency as the most important stakeholder attribute. ${ }^{50}$ Indeed, there are examples where Finnish businessmen expressed concern about the slow speed of correspondence: Joachim Donner, for example, stated in his letter to Torlades \& Co. in Lisbon that he not had received a letter dated by Torlades in January 1813 until November of that year. ${ }^{51}$

We did not include shipmasters in the calculations for Table 2, as the letters addressed to them were sent to various harbours all over the world. However, shipmasters were certainly among the contacts that possessed urgency as a stakeholder attribute. As stated before, they were the shipowners" "first-grade" agencies abroad, intermediaries they had to trust. Therefore, shipowners 
waited impatiently for any news from their masters. Some shipowners, like Fredrik Sovelius Junior, even blamed the shipmasters for neglecting to send information to them. Captain A. Cannelin, for example, got a number of acrimonious letters in 1852 in which Sovelius accused him of not having sent enough letters to him, thus depriving him of vital information. Sovelius even demanded that in the future Cannelin should send to him at least three letters from each port the ship visited during its voyages. $^{52}$

The shipowners did not always know where their ships were to sail. Therefore, they tried to reach their masters by sending letters to the most important ports for which orders had been placed - like Falmouth in Britain or Elsinore in the Danish Sound. Joachim Donner, for example, tried his best to reach his shipmaster C. F. Tuderus in 1818. The captain was arriving in the Baltic Sea from Portugal with a full cargo of salt onboard the ship "Alexander I". Just before the ship departed from Portugal in April, the captain received orders that the cargo should be taken to Riga. In May Donner wrote to a local business agent in Elsinore to deliver a letter to the shipmaster when he arrived instructing the cargo to be transported instead to Reval (Tallin). Soon after this message, Donner found out that the price of salt in Reval was falling, and new orders were sent that the cargo should instead be delivered to some Finnish harbour. These orders, however, never reached the captain, as the ship passed through the Danish Sound on the very same day the latest instructions were written in the home port. Therefore, according to the last orders that the master had received, the ship sailed directly to Reval, and the cargo was sold without profit. ${ }^{53}$

To sum up, urgency was a vital stakeholder attribute even in early modern international trade, though the possibilities to deliver messages rapidly were constrained by the low speed of communications. Indeed, as Brown and Duguid (1999) have stressed, the speed of communication surpassed the speed of human travel only when the telegraph arrived. ${ }^{54}$ Urgency was especially salient to businessmen when the time span between exchanges stretched so interminably. Market fluctuations and changes in creditworthiness could alter decision makers' wishes months before letters could convey those wishes to their agents abroad.

\section{Conclusion}

The aim of this article has been to introduce possible tools for measuring social capital in an historical context. Social capital has been here understood as assets available through well- 
functioning networks, such as stakeholder relations. As the historical data available from the chosen early modern period do not describe all the aspects of the relationships, we have made some assumptions and generalizations. Communication over distances during this period took place by means of letters, which also allows us to trace situations and contacts in retrospect, making assumptions and generalizations as necessary. To measure social capital, we applied the different relationship attributes associated with stakeholder thinking. We analyzed the concept of power through the value of trade, frequency through the number of transactions, legitimacy through third party-enforcement and urgency through response times.

The results of this study both create and exploit history. Firstly, we create a history narrative by our conclusion that social capital was similar in the early modern era to what it is today: only the relative importance of the attributes appear to have been different. The results seem to confirm the importance of all the attributes of legitimacy, power and urgency in stakeholder relations, and to put the significance of frequency higher than its present-day importance. This difference in frequency's significance no doubt follows from the greater ease and speed of business communications since the availability of the telegraph.

Secondly, the inquiry also enables us to learn from history, namely, to develop recently invented concepts further. Most trade did not take place only with definitive stakeholders; rather the frequency and continuity of the contacts were of the utmost importance. This, we argue, should be acknowledged in today's theories of social capital. Scholars of social capital have emphasized the importance of trust ${ }^{55}$, and early modern era transactions indicate that frequency and repetition were important to create this trust. Our empirical evidence also shows that the actors tended to expend a lot of effort and energy on exploratory occasional contacts, though most of the business was handled through a fairly limited number of actors who obviously possessed social capital. Even today, firms struggle to balance apparently inefficient investments in expanding their contacts against the merits of enhancing "the regulars," contacts already known to be reliable and with whom they have built reserves of social capital. ${ }^{56} \mathrm{New}$ aspiring contacts do not always offer the best possible solutions.

Our analytical tools can help to define the different stakeholder attributes contributing to social capital in early modern trade. How the actors in early modern trade seek to take advantage of them should be addressed in future studies. As knowledge about social capital increases, the possibilities of applying it broaden, furthering its applications in historical contexts. 


\section{Archival sources and their abbreviations}

Finnish National Archives (Helsinki, Finland), Donner Archives, Donner trading house (FNAD), Correspondence and ledgers 1813-1850.

Finnish National Archives (Helsinki, Finland), Donner Archives, Malm trading house (FNADM), Correspondence and ledgers 1820-1890.

K.H. Renlund Museum (Kokkola, Finland), Donner Archives (KHRm), Correspondence and ledgers 1814-1854.

Oulu Provincial Archives (Oulu, Finland), Archives of the Bergbom trading house (OPAB), Circular letters received 1820-1850.

Oulu Provincial Archives (Oulu, Finland), Sovelius Archives (OPAS), Lang \& Co. trading house, Correspondence and ledgers 1821-1852.

Vaasa Provincial Archives (Vaasa, Finland), Falander-Wasastjerna trading house (VPAF), Correspondence and ledgers 1781-1815.

\section{References}

Alanen, Aulis J. Der Aussenhandel und die Schiffahrt Finnlands im 18. Jahrhundert. Helsinki, 1957.

Almquist, Joh. Ax., Kommerskollegium och riksens ständers manufakturkontor samt konsulsstaten. Administrativa och biografiska anteckningar. Meddelanden från Svenska riskarkivet.

Stockholm: P. A. Nordstedt \& Söner, 1912-1915.

Bonsdorff, Lars G. von. En köpman och hans värld. Ekenäs, 1977.

Bonsdorff, Lars G. von. Kommerserådet. Ekenäs, 1980.

Bourdieu, P. "The Forms of Capital". In Education: Culture, Economy, and Society, edited by A. H. Halsey, H. Lauder, P. Brown \& A. Stuart Wells. Oxford: Oxford University Press, 1997: 4659.

Brenner, S. "Stakeholder Theory of the Firm: Its Consistency with Current Management Techniques." In Understanding Stakeholder Thinking, edited by Juha Näsi. Jyväskylä: LRSJulkaisut, 1995.

Brown, John Seely and Paul Duguid. The Social Life of Information. Boston (Mass.): Harvard Business School Press., 1999.

Calton, J.M. and N.B. Kurland. "A Theory of Stakeholder Enabling. Giving voice to an Emerging Postmodern Praxis of Organizational Discourse." In Postmodern Management and Organizational Theory, edited by D.M. Boje, R.P. Gephart Jr and T.J. Thatchenkery. Thousand Lakes: Sage, 1996.

Carroll, A. Business \& Society - Ethics and stakeholder management. Cincinnati OH: southWestern Publishing, 1989. 
Casson, Mark. "Entrepreneurial Networks; A Theoretical Perspective." In Entrepreneurial Networks and Business Culture, edited by Clara Eugenia Núñez. Sevilla: Proceedings. Twelfth International Economic History Congress., 1998.

Chalmeta, R. "Methodology for customer relationship management". Journal of Systems and Software 79, no. 7 (2006): 1015-1024.

Clarkson, M.B.E. "A Stakeholder Framework for Analysing and Evaluating Corporate Social Performance". Academy of Management Review 20, no. 1 (1995): 92-117.

Coleman, J. C. Foundations of Social Theory. Cambridge, Mass.: Harvard University Press, 1990.

Cook, Karen S., Richard M. Emerson and Mary R. Gillmore. "The Distribution of Power in Exchange Networks: Theory and Experimental Results". American Journal of Sociology 89, no. 2 (1983): 275-305.

Curry, J. and A. Curry. The Customer Marketing Method: How to Implement and Profit from Customer Relationship Management: Free Press, 2000.

Deephouse, D. and S. Carter. "An Examination of Differences Between Organizational Legitimacy and Organizational Reputation". Journal of Management Studies 42, no. 2 (2005): 329-360.

Dennison, T. K. and Sheilah Ogilvie. "Serfdom and Social Capital in Bohemia and Russia". The Economic History Review 60, no. 3 (2007): 513-544.

Donaldson, T. and L. Preston. "The Stakeholder Theory of the Corporation: Concepts, Evidence, Implications". Academy of Management Review 20, (1995): 65-91.

Emerson, Richard M. "Power-Dependence Relations". American Sociological Review 27, no. 1 (1962): 31-41.

Etzioni, A. Modern Organizations. Englewood Cliffs, NJ: Prentice-Hall, Inc, 1964.

Farr, J. "Social Capital: A Conceptual History". Political Theory 32, no. 1 (2004): 6-33.

Freeman, R.E. Strategic Management. A Stakeholder Approach. Boston, MA: Pitman, 1984.

Granovetter, Mark. "The Strength of Weak Ties". American Journal of Sociology 78, no. 6 (1973): $1360-1380$

Greif, Avner. "Reputation and Coalitions in Medieval Trade: Evidence on the Maghribi Traders". The Journal of Economic History 49, no. 4 (1989): 857-882.

Hosmer, L. T. "Trust: The connecting link between organizational theory and philosophical ethics". Academy of Management Review 20, no. 2, (1995): 379-403.

Jones, Charles A. International Business in the Nineteenth Century. The Rise and Fall of a Cosmopolitan Bourgeoisie. Brighton: Wheatsheaf, 1987.

Karonen, Petri. Patruunat ja poliitikot. Yritysjohtajat taloudellisina ja poliittisina toimijoina Suomessa 1600 - 1920. Helsinki: SKS, 2004.

Kaukiainen, Yrjö. A History of Finnish Shipping. London-New York, 1993.

Laakso, Seija-Riitta. Across the Oceans. Development of Overseas Business Information Transmission 1815-1875. Helsinki: SKS, 2007.

Ledingham, J. and S. Bruning eds., Public Relations as Relationship Management. A Relational Approach to the Study and Practice of Public Relations. Mahwah, NJ: Lawrence Erlbaum Associates, 2000.

Lin, Nan. Social Capital: A Theory of Social Structure. Port Chester, NY.: Cambridge University Press, 2001.

Luoma-aho, Vilma. Faith-holders as Social Capital of Finnish Public Organisations. Jyväskylä: Jyväskylä Studies in Humanities 42, 2005.

Luoma-aho, Vilma. "Viestintä, maine ja organisaation sosiaalinen pääoma. (Communication, reputation and organisational social capital)." In Sosiaalisen pääoman kentät (Fields of Social Capital), edited by Pertti Jokivuori. Jyväskylä: Minerva, 2005b: 393-413.

Luoma-aho, Vilma. "Neutral Reputation and Public Sector Organizations". Corporate Reputation Review 10, no. 2 (2007): 124-143. 
Mailath, G. and L. Samuelson. Repeated Games and Reputations. Long-Run Relationships. Oxford: Oxford University Press, 2006.

McCusker, John. "The Demise of Distance. The Business Press and the Origins of the Information Revolution in the Early Modern Atlantic World". The American Historical Review 110, no. 2 (2005): 295-321.

Mitchell, R., B. Agle and D. Wood. "Toward a Theory of Stakeholder Identification and Salience: Defining the Principle of Who and What Really Counts". Academy of Managament Review 22, no. 4 (1997): 853-886.

Müller, Leos. Consuls, Corsairs, and Commerce. The Swedish Consular Service and Long-Distance Shipping, 1720-1815. Uppsala: Acta Universitatis Upsaliensis, 2004.

Müller, Leos and Jari Ojala. "Consular Services of the Nordic Countries during the Eighteenth and Nineteenth Centuries: Did They Really Work?" In Resources and Infrastructures in the Maritime Economy. Research in Maritime History No. 22., edited by Gordon Boyce and Richard Gorski. St. John's: Memorial University of Newfoundland - International Maritime Economic History Association, 2002: 23-41.

Nikula, Oscar. Malmska handelshuset i Jacobstad. Helsingfors: Svenska litteratursällskapet i Finland, 1948.

North, Douglass C. Structure and Change in Economic History. New York \& London: W. W. Norton \& Company, 1981.

North, Douglass C. Institutions, Institutional Change and Economic Performance. Cambridge-New York: Cambridge University Press, 1990.

Näsi, J. "What is Stakeholder Thinking? A Snapshot of a Social Theory of the firm." In Understanding Stakeholder Thinking, edited by Juha Näsi. Jyväskylä: LRS-Julkaisut, 1995.

Offer, Avner. "Between the Gift and the Market: The Economy of Regard". Economic History Review 50, no. 3 (1997): 450 - 476.

Ogilvie, Sheilah. "Guilds, Efficiency, and Social Capital: Evidence from German Proto-Industry". The Economic History Review LVII, no. 2 (2004): 286-333.

Ojala, Jari. "Approaching Europe: The Merchant Networks between Finland and Europe during the Eighteenth and Nineteenth Centuries". European Review of Economic History 1, no. 3 (1997): 323-352.

Ojala, Jari. "Patriarkan kuolema." In Arjen valta. Suomalaisen yhteiskunnan patriarkaalisesta järjestyksestä myöhäiskeskiajalta teollistumisen kynnykselle (v. 1450 - 1860). Historiallinen Arkisto 116, edited by Piia Einonen and Petri Karonen. Helsinki: SKS 2002: 221-253.

Ojala, Jari. "The Problem of Information in the Late Eighteenth and Early Nineteenth Century Shipping: A Finnish Case". International Journal of Maritime History XIV, no. 1 (2002): 189-208.

Pfeffer, Jeffrey and Gerald R. Salancik. The External Control of Organizations: a Resource Dependence Perspective. New York: Harper \& Row, Publishers, 1978.

Pizzorno, A. Resources of Social Capital: Reputation and Visibility. Keynote speech, ECSR Summer School on Social Capital, Trento Italy, 2004.

Polanyi, K. The Great Transformation. The Political and Economic Origins of our Time. Boston, 1944.

Pollard, Sidney. The Genesis of Modern Management. A Study of the Industrial Revolution in Great Britain. London, 1965.

Putnam, R. D. Bowling Alone: The Collapse and Revival of American Community. New York: Simon \& Schuster, 2000.

Putnam, R. D., R. Leonardi and R. Y. Nanetti. Making Democracy Work: Civic Traditions in Modern Italy. Princeton, NJ: Princeton University Press, 1993.

Rhenman, E. Företagsdemokrati och företagsorganization (In Swedish, Industrial Democracy and Business Organization). Stockholm: Thule, 1964. 
Rothstein, B. Sociala fällor och tillitens problem. Stockholm: SNS Förlag, 2003.

Savage, G., K. Campbell, T. Patman and L. Nunnelley. "Beyond Managed Costs. Current Trends and Future Issues". Health Care Management Review 25, no. 1 (2000): 93-108.

Stobart, Jon. "Information, trust and reputation. Shaping a merchant elite in early 18 th-century England". Scandinavian Journal of History 30, no. 3/4 (2005): 298-307.

Suchman, M. C. "Managing Legitimacy: Strategic and Institutional Approaches". Academy of Management Review 20, no. 3 (1995): 571-610.

Tielhof, Milja van. The 'Mother of All Trades': The Baltic Grain Trade in Amsterdam from the Late Sixteenth to the Early Nineteenth Century. Leiden: Brill Academic Publishers, 2002.

Åström, Sven-Erik. From Tar to Timber. Studies in Northeast European Forest Exploitation and Foreign Trade 1660-1860. Helsinki: Societas Scientiarum Fennica, 1988.

\footnotetext{
${ }^{1}$ Freeman, Strategic, 31; Mitchell, et al., Toward, 853 - 886; Luoma-aho, Faith-holders.
}

${ }^{2}$ Coleman, Foundations; Lin, Social Capital; Putnam, Bowling Alone; Putnam, et al., Making Work; Rothstein, Sociala

${ }^{3}$ Luoma-aho, Viestintä, 393-413; Luoma-aho, Faith-holders.

${ }^{4}$ Lin, Social Capital; Putnam, Bowling Alone; Rothstein, Sociala.

${ }^{5}$ North, Structure and Change, 204-205; North, Institutions, 64-65; Polanyi, Great Transformation; Greif, Reputation, $857-822$.

${ }^{6}$ Offer, Between the Gift, 450; Ojala, The Problem of Information ..., 192.

${ }^{7}$ Kaukiainen, A History of Finnish Shipping, 65 - On Baltic and Finnish trade and shipping see Alanen, Aussenhandel; Tielhof, Mother of All Trades; Åström, From Tar to Timber.

${ }^{8}$ On the evolution of the concept, see Farr, Social Capital, 6-33. - See also Dennison and Ogilvie, Serfdom, 513-515.

${ }^{9}$ Casson, Entrepreneurial Networks, 21; Stobart, Information, 299; Offer, Between the Gift, 450-451. - See also Ogilvie, Guilds, 288.

${ }^{10}$ Jones, International Business, 191; Casson, Entrepreneurial Networks, 13-28; Pollard, Genesis, $209-249$.

${ }^{11}$ Nevertheless, intermediates such as shipmasters used oral communication with the overseas business partners.

However, even in these cases masters usually reported carefully about these discussions to their principals at home.

${ }^{12}$ Bourdieu, The forms of capital, 51. - See also Coleman, Foundations; Lin, Social Capital; Rothstein, Sociala.

${ }^{13}$ Putnam, Bowling Alone; Putnam et al., Making Work.

${ }^{14}$ Bourdieu, The forms of capital, 52

${ }^{15}$ Luoma-aho, Viestintä.

${ }^{16}$ Freeman, Strategic; Näsi, What is Stakeholder.

${ }^{17}$ Calton and Kurland, Theory of Stakeholder.

${ }^{18}$ Donaldson and Preston, Stakeholder Theory, 65-91.

${ }^{19}$ Carroll, Business and Society; Clarkson, Stakeholder Framework, 92-117; Savage, et al., Beyond, 93-108; Freeman, Strategic; Pizzorno, Resources of Social Capital.

${ }^{20}$ Mitchell, et al., Toward, $853-886$.

${ }^{21}$ Luoma-aho, Faith-holders.

${ }^{22}$ Luoma-aho, Faith-holders. - See also Mailath and Samuelson, Repeated Games.

${ }^{23}$ Rothstein, Sociala.

${ }^{24}$ On Falander see Karonen, Patruunat,186-207 and on Franzén see Ojala, Patriarkan, 221-253

${ }^{25}$ The value of trade was taken from the account books. This caused certain difficulties, as we did not have ledgers available from all cross cutting years. Thus, in case of Falander the 1781 contacts in letters were compared to ledgers from 1785. From other years in his case we did have all ledgers available. In case of Franzén, more straight forward analysis was done, namely, only the most important business partners were selected from the ledgers in first place. Thus, the selection is not as exact as in the case of Falander.

${ }^{26}$ Names of Swedish consuls adapted from Almquist, Kommerskollgeium, 345-448.

${ }^{27}$ Casson, Entrepreneurial Networks, 21; Ojala, Approaching, 323-325.

${ }^{28}$ Granovetter, Weak Ties, 1369-1372, 1376. See also Ojala, Problem of Information, 192-193

${ }^{29}$ Müller and Ojala, Consular Services, $37-38$.

${ }^{30}$ Luoma-aho, Faith-holders.

${ }^{31}$ Luoma-aho, Faith-holders, 142.

${ }^{32}$ Torlades \& Co. in Lisbon and Setubal, for example, was equally important to Joachim Donner in the first years of the nineteenth century as for his grandsons at the end of the century. FNAD, Joachim Donner (Kokkola) to Torlades \& Co (Lisbon) November 24, 1814. KHRm, Carl Donner (Kokkola) to Torlades \& Co (Setubal) February 23, 1872. - See also Casson, Entrepreneurial Networks, 17-18; Stobart, Information, 298-299; Mailath and Samuelson, Repeated Games. 
${ }^{33}$ OPAS, Zacharias Franzén (Raahe) to Gustaf Sterky (St. Petersburg) July 21, 1827.

${ }^{34}$ The Sterky trading house was established in 1805 and was widely used by Finnish merchants up to 1892, when the last in a series of principals of the company died. Nikula, Malmska, 324-325, 329, 441; Bonsdorff, Köpman, 164; Bonsdorff, Kommerseråd, 15.

${ }^{35}$ Mitchell, et al., Toward; Brenner, Stakeholder; Freeman, Strategic

${ }^{36}$ Pfeffer and Salancik, External Control.

${ }^{37}$ See e.g. Cook, et al., Distribution of Power; Emerson, Power-Dependence, Pfeffer and Salancik, External Control, 275-305.

${ }^{38}$ OPAS, Zacharias Franzén (Raahe) to And. Wener (Stocholm) January 1, 1843; to Johan \& Carl Scharp (Stockholm) March 13, 1843 and January 22, 1844; Ledgers, Daniel Sutthoff \& Co. 1839 - 1851.

${ }^{39}$ Nikula, Malmska, 272, 327-328, 439.

${ }^{40}$ Suchman, Managing, 571-610.

${ }^{41}$ Carroll, Business and Society.

${ }^{42}$ Hosmer, Trust, 386; Deephouse and Carter, Between Organizational Legitimacy.

${ }^{43}$ OPAB, Fredholm \& Ekström (Marseilles), Circular, April 30, 1856; Moller's enka \& Son (Lisbon), Circular March 1, 1841.

${ }^{44}$ VPAF, Abraham Falander (Vaasa) to Jan Bte. Lautier (Stocholm) May 3, 1781 and June 18, 1781.

${ }^{45}$ FNADM, Clay \& Square (Hull) account sent to Peter Malm Jr. September 12, 1829; Rew \& Prescott \& Co (London) account of insurance for "The Enterprise" July 1, 1829; Clay \& Co (Hull) to Peter Malm (Pietarsaari) November 28, 1829. - Compare Nikula, Malmska, 93-96.

${ }^{46}$ Müller, Consuls.

${ }^{47}$ Müller and Ojala, Consular Services, 37.

${ }^{48}$ Mitchell, et al., Toward.

${ }^{49}$ See especially McCusker, Demise of Distance, 295-321. - On information circles see Laakso, Across, 38-40.

${ }^{50}$ As the number of different towns traded with was fairly considerable, in certain cases there are only a few examples per town available to calculate urgency with. Therefore, urgency my in some case be slightly over-estimated. Nevertheless, in the most important trading areas the number of cases is significant enough to reveal the importance of urgency.

${ }^{51}$ FNAD, Joachim Donner (Kokkola) to Torlades \& Co. (Lisbon) November 23, 1813; Ojala, The Problem of Information, 195.

${ }^{52}$ OPAS, Fredrik Sovelius (Raahe) to Captain A. Cannelin (Akyab) February 2, 1852 and to Cannelin (Amsterdam) November 11, 1852.

${ }^{53}$ KHRm, Joachim Donner (Kokkola) to C. P. Tuderus (Lisbon) April 4, 1818; (Elsinore) May 24, 1818; June 14, 1818; June 25, 1818; August 1, 1818; August 23, 1818; (Reval) August 23, 1818.

${ }_{54}$ Brown and Duguid, The Social Life of Information, 17.

${ }^{55}$ Lin, Social Capital; Putnam, Bowling Alone; Putnam, et al., Making Work; Rothstein, Sociala.

${ }^{56}$ On customer relations management see: Curry and Curry, Customer Marketing; and on relationship management: Ledingham and Bruning, Public Relations; Chalmeta, Methodology; Luoma-aho, Neutral reputation, 124-143. 